症例

ドレナージが無効であった男性同性愛者のアメーバ性肝膿瘍の 1 例

仁多町立仁多病院外科

鈴木賢二春日 正己

39 歳男性同性愛者に発症したアメーバ性肝膿堭の 1 例を経験した. 右季肋部の圧痛と 熱発を主訴として他院から紹介され入院, 肝 S 7 に径 $8 \mathrm{~cm}$ の晠瘍を認めた. エコーガイ ド下経皮的膿瘍ドレナージを施行したが効果はなかった. 2 日後, 膿堭が腹腔内に穿孔し たため，開腹・腹腔ドレナージ術を施行した，その後メトロニダソール投与を開始しこ れが奏効，全身状態は改善した。ドレーンからの逆行性細菌感染を併発したため抜去時 期がおくれたが抗生剤でコントロール後抜去し徒歩退院した。

アメーバ症は本邦では 1980 年以降急速に增加し，その多くが男性同性愛者間で sexually transmitted amebiasis の形で流行していると考えられる. 診断は血清学的検査が最 も有効である．肝膿場をみたらアメーバ性を疑い，早期にメトロニダゾールを投与する ことが重要で，ドレナージは特殊な場合を除き適応にはならないと考えられた。

索引用語：アメーバ性肝膿瘍, 肝膿演ドレナージ, 男性同性愛者

\section{舶言}

本邦では 1970 年代には年間 10 例前後の届け出しか なかった赤㾰アメーバ症は, 1980 年代に入り都市部を 中心に急激に增加し，それに伴いアメーバ性肝膿瘍も 增加している.この增加の主要な原因は男性同性愛者 の sexually transmitted amebiasisによるものと思わ れる.メトロニダソール投与と共に，アメーバ性肝膿 场には経皮的膿場ドレナージを推奖する報告が多い。 われわれは男性同性愛者に発症し、経皮的ドレナージ が無効で腹腔内に穿孔し沉発性腹膜炎をきたしたア メーバ性肝膿瘍の 1 例を経験したので文献的考察を加 えて報告する。

患者 : 39 歳, 男性.

主訴: 右季肋部痛, 発熱.

家菻歴：特記事項なし.

既往歴：9 年前, 淋病に感染, 抗生绪投与を受け治瘾 した. 5 年前から男性同性爱者との交遊があった。

現病歷：4 力月前から水梯性下㾰があり，軽快と增 悪を繰り返していた。 1997 年 8 月 20 日, 全身倦急感・ 心裔部不快感が出現, さらに心窝部痛・高熱が相次い で出現し，近医受診し抗生剤投与等を受けたが軽快し

1998 年 2 月 23 日受付 1999 年 1 月 12 日探用
なかった. 8 月 29 日急性胆衰炎と診断され当院内科に 紹介，入院となった。

入院時現症：身長 $164.5 \mathrm{~cm}$, 体重 $53.3 \mathrm{~kg}$, 体温 38.0 ${ }^{\circ} \mathrm{C}$. 血圧 $120 / 70 \mathrm{mmHg}$, 脈拍 120 /分, 整. 眼瞼 - 眼球 結膜に黄疸，貣血なし．心，肺に異常なし，右季肋部 で肝を 2 横指触れ著明な圧痛を認めた，脾腫, 腹水な く，神経学的異常を認めなかった。

入院後経過：入院時検查成績を Table 1 に示す。末 梢血液検查で高度の白血球增加がみられた，血液生化 学検查では血清ビリルビンおよびトランスアミナーゼ の軽度の上昇，CRPの著明な上昇を認めた。梅毒検查 では TPHA, ガラス板法ともに陽性であった. 腹部 CT 像 (Fig. 1 a) では肝 S 7 に径 $8 \mathrm{~cm}$, 単房性, 被膜を有 する内部不均一の豪胞性病変がみられ, 著明な肝腫大 を伴っていた，腹部超音波像も同様の所見であった。 以上より肝膿激が疑われ，入院時より抗生剂投与が開 始されたが軽快せず，9月1日当科紹介となった。臨床 経過を Fig. 2 に示す. 9 月 2 日超音波ガイド下に経皮 的䐷瘍ドレナージを行い $10 \mathrm{Fr}$. バルーン付きカテー

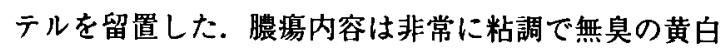
色のゲルと，上清と思われる透明な液体からなり，紐 菌培盖の結果は陰性であった。しかし膿瘍は十分にド レナージされず，9月 4 日腹痛が急激に增強し, 膿瘍腔 の造影で肝右葉頂部で横隔膜下に穿孔を認めたため, 
Table 1 Laboratory findings on admission

\begin{tabular}{lc|ll}
\hline WBC & $244 \times 10^{2} / \mu \mathrm{l}$ & GRP & $27.5 \mathrm{mg} / \mathrm{dl}$ \\
$\mathrm{RBC}$ & $494 \times 10^{4} / \mu \mathrm{l}$ & Stool occ. bloo & $(-)$ \\
$\mathrm{Hb}$ & $15.6 \mathrm{~g} / \mathrm{dl}$ & HBsAg & $(-)$ \\
$\mathrm{Plt}$ & $22 \times 10^{4} / \mu \mathrm{l}$ & HCV & $(-)$ \\
TP & $5.77 \mathrm{~g} / \mathrm{dl}$ & TPHA & $(+)$ \\
Alb & $3.28 \mathrm{~g} / \mathrm{dl}$ & VDRL & $(+)$ \\
T.bil & $1.51 \mathrm{mg} / \mathrm{dl}$ & HIV & $(-)$ \\
D. bil & $0.90 \mathrm{mg} / \mathrm{dl}$ & AFP & $0.9 \mathrm{ng} / \mathrm{ml}$ \\
GOT & $54 \mathrm{IU} / \mathrm{l}$ & CEA & $0.6 \mathrm{ng} / \mathrm{ml}$ \\
GPT & $90 \mathrm{IU} / \mathrm{l}$ & CA19-9 & $1.9 \mathrm{U} / \mathrm{ml}$ \\
ALP & $6.8 \mathrm{~K} . \mathrm{A.U}$ & & \\
$\gamma-$ GTP & $47 \mu \mathrm{mol} /$ & & \\
T. cho & $127 \mathrm{mg} / \mathrm{dl}$ & & \\
\hline
\end{tabular}

肝朖瘍破裂による汎発性腹膜炎と診断, 開腹・腹䏶ド レナージ術を施行した，肝膿瘍ドレナージ不良のため 数度のドレーン交換を行い，最終的には 9 月 6 日に 28 Fr.のシリコンチューブを肝内に留置した.

全身状態はさらに悪化し黄㾝が進行, DIC も併発し た. 9 月 8 日には血清総ビリルビン值 $10.96 \mathrm{mg} / \mathrm{dl}$ と最 高になった，抗生剤やドレナージに反応しないことか らアメーバ性肝膿瘍を疑い, 同日よりメトロニダゾー ル投与を開始した．経口搨取不能であったため，腟錠 $1,500 \mathrm{mg} /$ 日を直腸内投与した.この日を境に全身状態 は改善し黄㾝も徐々に正常化していった．9月5日の 赤浰アメーバ抗体は, 間接蛍光抗体法 1,600 倍, 受身赤 血球凝集法 80 倍と高値を示し,アメーバ性肝䝢瘍と確 定診断した. 9 月 13 日メトロニダゾールを $750 \mathrm{mg} /$ 日 の経口投与に変更した．全身状態の改善に比へ晨瘍腔 の縮小はみられず，ドレーンからの逆行性感染を併発 した，抗生剂で逆行性感染をコントロールした結果， 発熱を認めなくなりドレーン中の細菌が陰性になった ため 11 月 13 日膿瘍内ドレーンを抜去した，以後発熱 を認めず，全身状態も良好となった．経過中，供便， 肝膿場内朖汁ともに頻回の検索にもかかわらず赤峲ア メーバは認められなかった。後日，本症の再発性も考 虑して,メトロニダゾール $1.5 \mathrm{~g} /$ 日を 10 日間追加投与 した. 11 月 26 日の腹部 CTでも，内部は均一化してい るものの依然として大きな膿汮腔を認めた（Fig. 1 b) 全身状態は良好で 12 月 12 日徒歩退院した。退院後, 下部消化管内視鏡検查を施行したが明らかな大腸病変 は認められなかった．1998 年 8 月 28 日の CTでは膿 瘍腔は消失していた（Fig.1 c)。

$$
\text { 考察 }
$$

赤利アメーバ症は熱帯, 亜熱帯に多く先進国では比

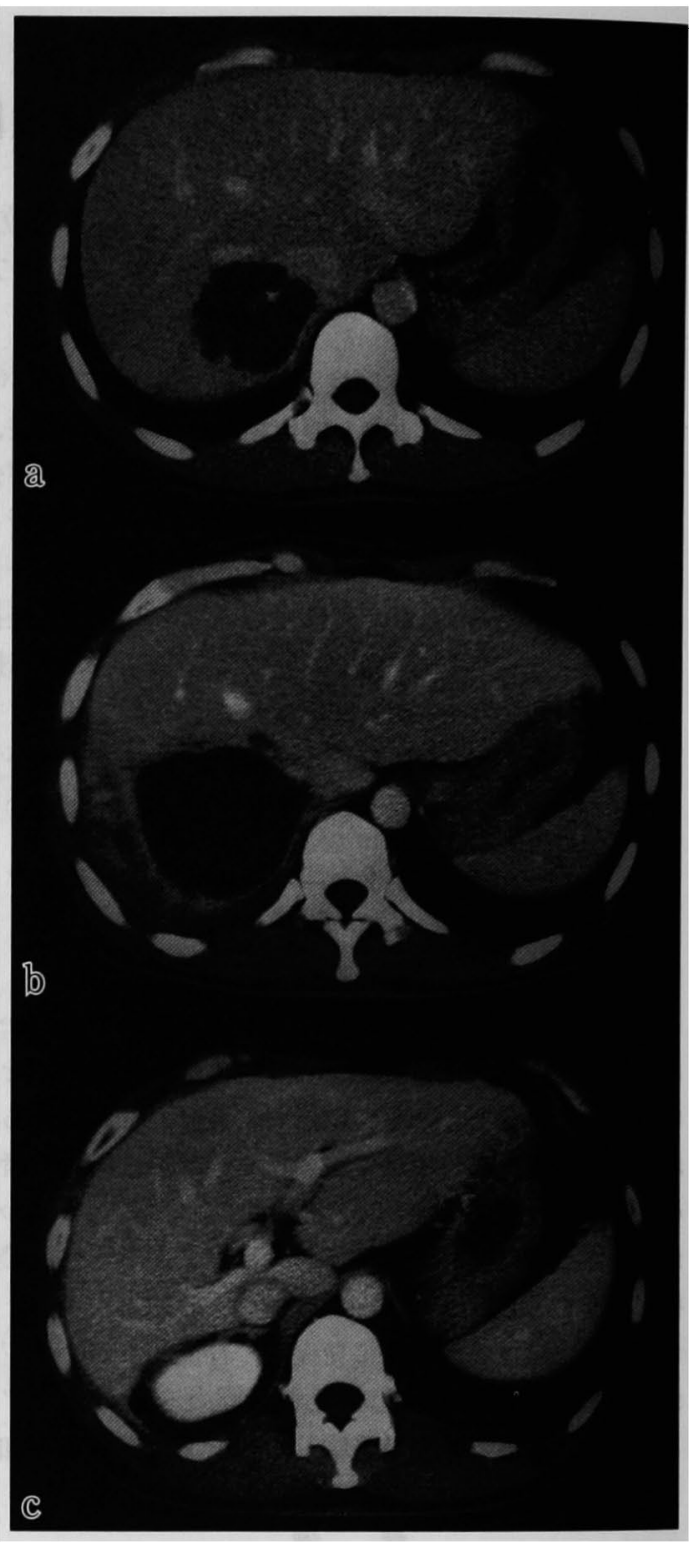

Fig. 1 CT : a) On an enhanced CT on admission, a heterogeneous low density area. $8 \mathrm{~cm}$ in diameter with a capsule, was shown on S 7 of the liver, accompanied by marked hepatomegaly. b) About three months after admission, inner wall of the low density area became smooth but its reduction in size was poor. c) About one year after admission, the cavity disappeared.

較的稀な疾患とされてきた，本邦でも厚生省の報告に よると，1960 年代から減少を示し 1970 年代には年間 10 例前後で推移してきたが, 1980 年以降急速に增加し 

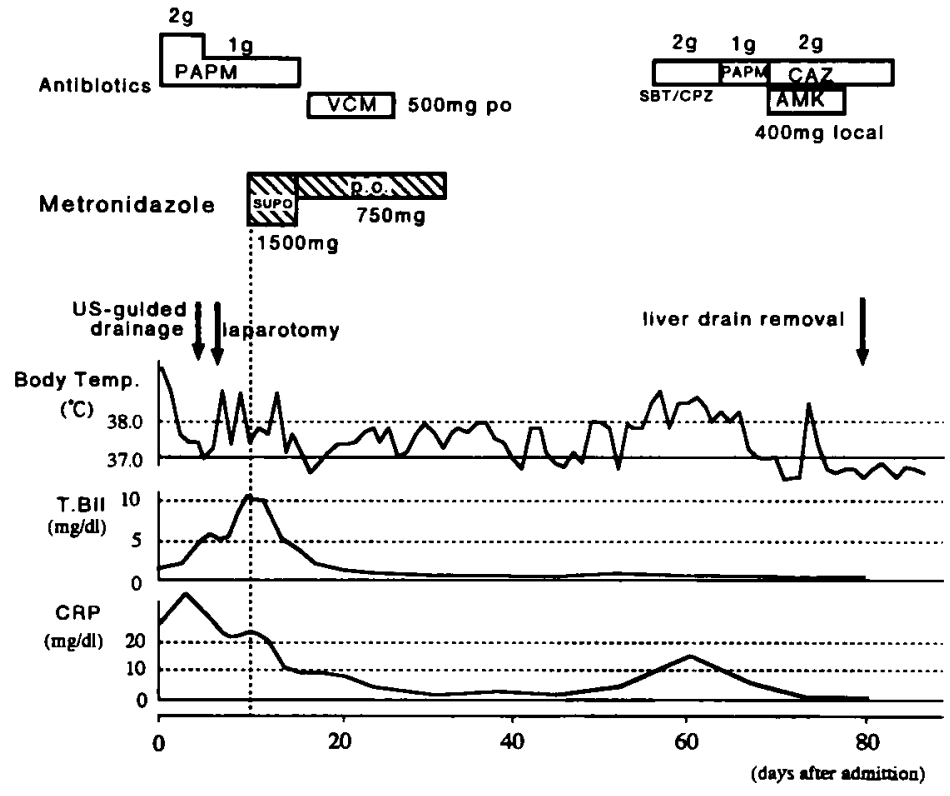

Fig. 2 Clinical course: Ultrasound-guided abscess drainage was performed on the 4 th day after admission. This drainage had no effect and generalized peritonitis occurred ; as a result, open peritoneal drainage was needed on the 6 th day. The patient's serum bilirubin level and overall general condition had been worsening ; after intrarectal metronidazole administration was started on the 10 th day, his serum bilirubin level and general condition recovered markedly.

1990 年代に入っても年間䄪 100 例が報告され，特に男 性の増加が著しい. 欧米では, 男性同性愛者間で sexually transmitted amebiasis として流行していることが 1980 年頃から相次いで報告, 証明され1/21, 口・性器並 びに口・肛門感染が感染経路とされる2. 北米・欧州 では男性同性要者の 20〜30\%に赤㾥アメーバ感染が 認められだ). 本邦でも，アメーバ性肝膿演・赤㾁ア メーバ症患者中 50〜 70\%の男性同性愛者を認め415), 欧米と同様に男性同性愛者間の流行が主体であろうと 推測される。 またこれらの患者の間に, 他の感染症, すなわち梅毒, C 型肝炎, HIV などが高率に合併する ことが知られており，診療に当たって十分に留意する 必要がある.

赤利アメーバの感染は成熟型咅子の経口摄取により 成立する，小腸で脱軎した虫体は盲腸に至り成熟し栄 盖型となる．この栄盖型は特定の条件下で大腸の組織 内に進入し周囲の組織を破壊し発症するとされてい 了.

従来, 赤利アメーバの感染者の大部分は cyst carrier で，10\%以下が宿主の抵抗力が低下したときにinva- sive amebiasis として発症すると考えられてきた。し かし, 近年の研究により, 赤痢アメーバには病原株と 非病原株が存在することが示されだ．従来赤痢ア メーバという名称で単一種とされた原虫は, 病原性で ある Entamoeba histolytica と非病原性の Entamoeba disparという，形態的に殆ど差のない 2 種よりなるこ とが明らかとなっだ. 欧米で同性愛者間に分布して いるアメーバは E. disparで，無症状の carrier である のに対し，わが国では高い頻度で E. histolytica が検出 され，大部分が有症状患者と推定される。この欧米と 本邦との差異の原因は不明だが、本邦のアメーバ症に 特徴的なこととして注目される。

腸アメーバ症は血行性に転移し肝膿瘍を形成する。 本邦では, 肝膿瘍発生頻度は欧米に比べかなり高率で, $30 \%$ 前後“'とされ，113 例のアメーバ症中 50 例 (44\%) が肝膿堭であったとの報告もある8).アメーバ性肝膿 瘍の症状は, 発熱, 上腹部痛, 肝腫大, 血液検査では 白血球增多，CRP 高值であるが，いずれも本症に特異 的なものではない．腹部 CT 並びに超音波検查により

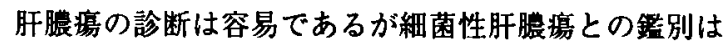


困難である．エコーガイド下経皮的ドレナージで特徴 的な内容液, すなわちチョコレートソースもしくはア ンチョビソース様の内容液を吸引すれば本症を強く疑 う. 膿湯中・䔬便中に赤病アメーバが認められれば診 断は確定的であるが陽性率は低く”，自験例でも，膿汁 ・䔬便中ともに赤制アメーバは認められなかった。診 断に最も有用なものは血清学的検査である. 赤血球凝 集反応, ゲル内沈降反応, 間接蛍光抗体法, カウンター 電気泳動法などが有用であり，腸アメーバ症で 81.8〜 90\%，アメーバ性肝膿塏ではほほ 100\%の陽性率を示 す(0)ため，本症を疑えば早期に血清学的検査を行うこ とが重要である. 判定には約 7 日前後を要するために 可及的早期の提出が望ましい.

治療の第一選択はメトロニダゾールである，極めて 強力な抗アメーバ作用をもち，効果も速やかである. $1,500 \mathrm{mg} /$ 日， 10 日前後が推奖されているが, 実験的発 癌性, 催奇形性から投与量を低く設定する動きにあ る゙”. 経口摄取不良例もしくは重症例では，デヒドロ エメチン $1 \mathrm{mg} / \mathrm{kg}$ (本症では市販されておらず, 熱帯 病治療薬の開発研究班で管理され，必要時分与される) の筋注が行われる，自験例では胵錠の直腸内投与を行 い速やかな症状の改善を見たが，直腸内投与に関する 薬理学的報告は見当たらない.

本症に対して肝膿瘍ドレナージは従来適応とはなら ず，例外的に内科的治療が奏効せず穿孔の危険のある 場合や細菌感染の合併した場合に限られるとされてき た (22 -14)が，膿演径が 3〜5 cm を越えるものではドレ ナージの併用が有用との報告もある ${ }^{(5)}$.

近年の本邦での報告では，メトロニダソール投与に 加え経皮的ドレナージを併用したものが多い6177. 。 の理由として，膿瘍の鑑別に苦虑することが多く朖汁 の性状が診断の糸口になること ${ }^{(8)}$, 超音波検查が発達 し比較的容易に穿刺もしくはドレナージが行えるよう になったことが考えられる.しかしこれらの報告では ドレナージが有効であったのか，メトロニダゾールが 有効であったのか不明確なものが多く、ドレナージの 有効性が証明されているとは言い難い。ドレナージに 難泚するあまり診断，治療開始までいたずらに時間が 経過したり，合併症を起こす可能性もある13!。また自 験例においては $28 \mathrm{Fr}$.という太いドレーンを留置し たが，膿場内容は非常に粘椆壊死物質であったためド レナージ効果はなく，長期留置により逆行性感染を合 併した。これらのことから, 破裂の危険の高い肝左葉 の大きな膿場を除き，ドレナージは第一選択としては
行うべきでないと思われる．自験例のように効果がな く ${ }^{199}$ ，破裂をきたした ${ }^{20)}$ 症例も報告されている.

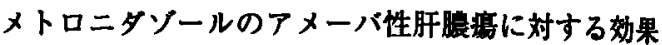
は非常に高く，再発をきたしたという報告はない。た だし、ドレナージ創にアメーバが残存する可能性を考 虑し，本例では 2 クール目のメトロニダソール投与を 行った. また, シストキャリアは感染源となるのでろ 〜6カ月観察を要するという意見"1)もある.

アメーバ性肝膿湯は従来考えられていたほど楼な笑 患ではなくなり，また男性同性愛者間という特殊な流 行が主因を占めるようになっている. 重要なことは診 断, 治療開始までの日数である.肝膿演をみたらアメー バ性の可能性を常に念頭におき，早期に血清学的検査 を施行し，無用なドレナージに時間を割くことなくメ トロニダゾールを投与すべきである．膿汁の性状の確 認ができなくはなるが, 高い血清学的診断能力を考え ても,安易にドレナージを行うべきではないと考えた.

\section{結 語}

男性同性愛者に発症したアメーバ性肝晨淘の 1 例を

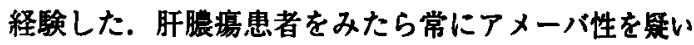
血清学的検查を行い，早期にメトロニダソールを投与 することが大事である.ドレナージは特殊な場合を除 き適応にはならない。

\section{文 献}

1) Marr JS : Amebiasis in New York City ; A changing pattern of transmission. Bull N Y Acad Med $57: 188-200,1981$

2) Markell EK, Havens RF, Kuritsubo RA, et al : Intestinal protozoa in homosexual men in the San Francisco Bay Area. Am J Trop Med Hyg 33 : 239-245, 1984

3) Allason-Jones E : Protozoal infections. Ed. by M. W.Adler, Diseases in the Homosexual Male. Springer-Verlag, London, 1988, p 59-75

4) Fujihara $T$, Nagai $Y$, Kubo $T$, et al : Amebic liver abscess. J Gastroenterol $31: 659-663,1996$

5）前田 清, 吉川和彦, 寺尾征史他：赤溂アメーバ症 10 例の臨床的検討一男性同性爱好者の感热. 日消 病会誌 $87: 1525-1531,1990$

6) Sargeaunt PG : Zymodemes of Entamoeba histlyrica. Ed. by Ravdin JI. Amebiasis. John Wiley and Sons, New York, 1988, p 370-387

7）竹内 勤：赤制アメーバ症. 歯界展望 $90: 230-$ 237,1997

8）增田剛太：最近しばしば通遇する原虫症一赤凩了 メーバ症。日医新報 $3659: 32-33,1994$

9）葉玉哲生, 調 函治, 内田雄三他：肺に穿通したア 
メーバ性肝膿瘖の経験と本邦報告 54 例の臨床的

検討. 外科 $44: 940-944,1982$

10）高田季久：赤痢アメーバ症. 最新医 $44: 730-$ 736,1989

11）竹内 勤, 関口恒存：アメーバ赤湖,アメーバ性肝

朖瑒. Mod Physician 14：1355-1358, 1994

12) Sepulveda B : Progress in amebiasis. Scand J Gastroent (Suppl) $77:$ 153-164. 1982

13) Robaeys G. Fevery J. Vandepitte J, et al : Amoebic liver abscess. Report of 5 cases. Acuta Clin Belg 38:295-301. 1983

14) Rustgi AK. Richter JM : Pyogenic and amebic liver abscess. Med Clin North Am 73 : 847, 1989

15) Conter RL. Pitt HA. Tompkins RK, et al : Differentiation of pyogenic from amebic hepatic abscesses. Surg Gynec Obst 162 : 114-120, 1986
16）葉玉哲生, 調 兆治, 内田雄三：アメーバ性肝膿 瘍. 肝・胆 $\cdot$ 膵 $13: 233-239,1986$

17）近藤秀則, 武田淖志, 飯島崇史他：経皮的朖瘍ドレ ナージが有効であったアメーバ性肝膿瘍の 1 治験 例. 臨外 $39: 1477-1481,1984$

18）佐藤直樹, 山下健一郎, 内野順一：アメーバ性なら びに寄生虫性肝膿場，臨消内科 $11: 1979-1986$ 。 1996

19）大元謙治, 井口泰孝, 高取敬子他：男性同性愛者に

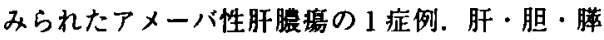
$31: 881-885,1995$

20）中村 徹, 大石哲也, 中山博司：沉発性腹膜炎をき たしたアメーバ性肝膿愓の 1 例. 日臨外医会誌 $52: 2703-2706,1991$

21) 相楽裕子：アメーバ症. 治療学 $52: 168-170$, 1991

\title{
A CASE OF AMEBIC LIVER ABSCESS IN A HOMOSEXUAL MAN WITH NO EFFECT OF PERCUTANEOUS DRAINAGE
}

\author{
Kenji SUZUKI and Masami KASUGA \\ Department of Surgery. Nita Town Hospital
}

We experienced a case of amebic liver abscess in a 39-year-old homosexual man. The patient was admitted to the hospital because of tenderness on the right hypochondrium and fever. Ultrasound and CT revealed a liver cyst $8 \mathrm{~cm}$ in diameter in $\mathrm{S} 7$. An ultrasound-guided percutaneous liver drainage was unsuccessful and the abscess ruptured into the peritoneal cavity two days after the percutaneous liver drainage. Open peritoneal drainage was performed. Their administration of metronidazole was started with good outcome; the patient was upgraded to good condition. A retrograde bacterial infection developed through the drainage tube. Antibiotics were administrated, which controlled the infection, and the tube was subsequently removed. The patient was discharged and left the hospital on foot.

There was a rapid increase in the number of reported cases of amebiasis in Japan after 1980. Most of these patients were thought to be homosexual men, and this disease is thought to be a prevalent sexually transmitted amebiasis. The serologic test is the most reliable option for diagnosis. An amebic abscess must be suspected if an abscess is found in the patient's liver. Metronidazole must be administrated to the patient as soon as possible. and the drainage procedure should be avoided except some special cases. 